\title{
Percepção subjetiva sobre criatividade: visão de árbitros e técnicos de Ginástica Rítmica
}

\author{
Priscila Raquel Tedesco da Costa Trevisan* \\ Gisele Maria Schwartz*
}

*Laboratório de Estudos do Lazer, Departamento de Educação Física, Instituto de Biociências, Universidade Estadual Paulista, Rio Claro, SP, Brasil.

\section{Resumo}

Este estudo qualitativo investigou os parâmetros de julgamento na percepção subjetiva sobre criatividade, na visão de árbitros e técnicos da modalidade Ginástica Rítmica. Para tanto, além de pesquisa bibliográfica, uma pesquisa exploratória contemplou a percepção de árbitros e técnicos desse esporte acerca da criatividade e seu envolvimento no desenvolvimento e julgamento dessa capacidade em âmbito competitivo. Como instrumento para coleta de dados, uma entrevista semiestruturada, a partir de questões elaboradas especificamente para esse estudo, foi aplicada individualmente a uma amostra intencional, selecionada por conveniência, composta por 14 participantes de ambos os sexos, sendo 05 árbitros de GR, com faixa etária entre 23 e 46 anos e experiência de 04 a 22 anos e, 09 técnicos de GR, com idades também entre 23 e 46 anos e tempo de prática de 06 a 20 anos. Todos foram atuantes em competições nacionais na vigência do ciclo olímpico 2013 a 2016. Os dados analisados descritivamente por meio da Técnica de Análise de Conteúdo apontam que esses participantes evidenciaram a criatividade como a capacidade de expressar o novo, o diferente, de forma extraordinária, perfeita e adequada às exigências desta modalidade. Por ter sua importância percebida subjetivamente, esses entrevistados salientaram a relevância do potencial criativo para enriquecer aspectos expressivos, artísticos e técnicos nas performances das atletas. 0 julgamento da criatividade em âmbito competitivo, ainda que não represente um quesito diretamente estabelecido nos códigos, é realizado de forma subjetiva, sendo esta percebida como um todo coeso, de teor artístico sobre o que é expresso nas séries, considerando, tanto elementos de Dificuldade, quanto de Execução. Esses dados contribuem para novas reflexões, ampliando a compreensão das relações existentes entre criatividade, esporte e arbitragem.

Palavras-chave: Ginástica; Criatividade motora; Esporte; Arbitragem.

\section{Introdução}

Profissionais e estudiosos de diversas áreas, entre as quais Educação ${ }^{1}$, Psicologia ${ }^{2}$, Educação Física $^{3}$, Artes ${ }^{4}$, sinalizam para a importância da criatividade. Entre os vários apontamentos, também está incluída a excelência no esporte, especialmente quando se atenta para a eficiência no desempenho do atleta em competições. Além disso, existem na literatura acadêmica, estudos que tratam das plausíveis relaçóes com distintas dimensóes que geram inúmeras controvérsias 5 .

Aquilo que é percebido como criativo no esporte tende a ser relacionado à precisáo na execução e na utilização dos movimentos técnicos, de forma que estes são reconhecidos como ações de valor, úteis e apropriados ao contexto. Dessa forma, o produto percebido como criativo, muitas vezes se refere a uma ideia, ação, jogada, movimento, ou outro, como algo que identifique o rendimento do atleta ${ }^{6,7}$.

Entretanto, essa é uma potencialidade que, apesar de almejada, pelas possibilidades de se ir muito além do desempenho e poder representar a expressão de diversos fatores combinados, podendo 
se tornar significada e relevante na evolução da prática esportiva, parece ainda não ser bem compreendida ${ }^{8}$. Muitas vezes, em competiçóes, atletas, treinadores e equipes vitoriosas são proclamados criativos, o que demonstra que esse julgamento faz parte ou, até, orienta inúmeras decisôes, mas é de igual modo, gerador de diferentes contrapontos entre as avaliaçóes.

Em modalidades como a Ginástica Rítmica, foco desse estudo, fatores que se configuram na qualidade artística e esportiva são muitas vezes permeados pela empatia e afinidade com as apresentaçóes, os quais ao serem subjetivamente percebidos, representam lacunas, tanto no que tange à aplicação dos regulamentos e critérios que orientam as práticas, como na literatura científica ${ }^{3}$. No esporte, em meio ao aprimoramento de técnicas, cumprimento de normas e regras instituídas, o uso do potencial criativo transcende e qualifica as habilidades motoras desenvolvidas e reforça o valor de práticas que vislumbrem a apreensão de aspectos significativos ao indivíduo. Entre outras, a criatividade é uma forma de desenvolver a capacidade de pensar, recriar e renovar ideias, na busca por soluçóes para problemas e adversidades que se apresentam ${ }^{9}$. Entretanto, essa potencialidade parece ser ainda pouco explorada no universo esportivo.

A criatividade é permeada pela capacidade de transformar o próprio movimento corporal, bem como, de perceber as possibilidades de como enriquecer as tarefas motoras. Trata-se de uma aptidáo do indivíduo para sentir, se conectar e gerar novas formas de movimento, as quais, ao serem moldadas por conteúdos imaginários, tornam possível colocar em evidência a imagem, o pensamento e a ação desejada por meio do movimento corpora ${ }^{10}$.

A criatividade é um fenômeno que envolve múltiplos aspectos e, portanto, grande complexidade 5 . Por esse motivo, gera discussóes em diferentes perspectivas, sendo proclamada como uma capacidade que implica na interação entre elementos cognitivos, características de personalidade, entre outras variáveis de natureza familiar, educacional e social'5.

Para se compreender em profundidade esse processo, é necessária uma abordagem que integre diferentes aspectos referentes à pessoa, ao processo, ao produto e ao contexto sociocultural sobre os quais converge uma ação criativa ${ }^{6,11,12}$. Em se tratando do esporte, pode-se referenciar a criatividade como uma capacidade de gerar, produzir uma grande quantidade de respostas, ideias e sentimentos, de forma não verbal, ou seja, por meio do movimento, usando critérios claros e apropriados ${ }^{13}$.

Neste contexto da Ginástica Rítmica (GR), foco desse estudo, as atividades físicas são combinadas a exercícios rítmicos e ao uso da música, o que pode tornar a criatividade um princípio constituinte em suas práticas. Ambos, atividades motoras e rítmicas podem contribuir para se fazer emergir o novo, por meio das habilidades e dificuldades associadas às dinâmicas de execução dos diversos movimentos corporais. Com seus princípios básicos inspirados em Rudolf Bode, Jaques Dalcroze e Francois Delsarte, entre outros que se reportam ao movimento como uma forma de linguagem e expressão corporal artística, a prática dessa modalidade se torna capaz de transcender os movimentos ginásticos mecanizados e técnicos ${ }^{15-17}$.

Como um esporte de natureza artística e prática essencialmente feminina, cada ação corporal inclui um valor artístico, desde o planejamento, elaboração e apresentação das coreografias, sendo a criatividade uma capacidade requisitada para o controle das técnicas corporais, uso dos aparelhos e da música ${ }^{14}$. Para o desenvolvimento de movimentos corporais ritmados e expressivos, preconiza-se a valorização da estética, da perfeição e da criatividade ${ }^{18,19}$. Dessa maneira, tornam-se característicos da GR movimentos ginásticos baseados em conhecimentos advindos da dança, da musicalidade, da expressão corporal associada ao manejo de aparelhos portáteis como corda, arco, bola, maças e fita.

As tarefas motoras envolvidas no treinamento dessa modalidade olímpica são de alta complexidade e risco, promovendo a aquisição de habilidades que favoreçam a coordenação e o desenvolvimento de importantes capacidades físicas, como flexibilidade, força, equilíbrio e outros na apropriação das técnicas específicas em prol do movimento perfeito ${ }^{20}$. Além disso, a busca constante pelo belo, um trabalho harmonioso entre as exigências artísticas, técnicas e estéticas, conduzidas por regras esportivas específicas, apontam para o fato de que a qualidade de execução não é conjugada apenas a partir de movimentos mecanizados ou tecnicamente perfeitos. Entre outros, aspectos de cunho subjetivo podem representar, justamente, o que diferencia, ou o que traz um valor maior à nota da ginasta em uma competição.

A necessidade de atendimento aos regulamentos estabelecidos por confederaçóes esportivas faz com que os conteúdos sejam selecionados em função do Código de Pontuação vigente, ao escalão etário 
e ao nível técnico da ginasta. O conjunto de regras implica na combinação de diferentes elementos, os quais se distinguem qualitativa e quantitativamente na composição das séries a serem apresentadas pelas ginastas ${ }^{20}$.

Os Códigos de Pontuação são os documentos oficiais, estabelecidos pela Federação Internacional de Ginástica (FIG), de acordo com cada uma das modalidades ginásticas. Esses Códigos, juntamente com os regulamentos internos de cada competição, têm a função de orientar, tanto a equipe de arbitragem em seus julgamentos, como a equipe técnica das ginastas, na elaboração das rotinas e composição das séries.

Para além dos elementos já registrados e valorizados no Código de Pontuação, existe um repertório técnico ainda a se criar, por meio daquilo que surge como novo e original ${ }^{20}$. No devir das competiçóes, a lista de elementos já conhecidos é ampliada e diversos fatores são incorporados nas relaçóes entre movimento corporal, expressão, aparelho e música. Estes, visando ser adequados e atender às exigências da modalidade, são permeados pelo uso do potencial criativo, seja pelos técnicos, na articulação dos seus conhecimentos para compor as séries, e pelas ginastas, para expressarem o que foi apreendido no treinamento, de forma a sensibilizar, tanto o público, quanto a banca de arbitragem.

Conforme a ginasta vai adquirindo maior excelência em seu desempenho, cada vez mais as dificuldades e a complexidade dos movimentos aumentam e, dessa forma, para se diferenciar, muitos elementos corporais passam a ser recriados, no intuito de que aquela performance seja reconhecida por seu valor, beleza e diferencial. Devido às individualidades de cada atleta, muitos aspectos subjetivos se sobrepóem, sendo necessários ajustes para valorizar o que cada ginasta tem de melhor. Nesse sentido, a criatividade pode ser um meio para transformar as vivências esportivas na expressão de algo diferenciado, prazeroso e significativo, contribuindo, assim, para reforçar a essência desse esporte como um fenômeno artístico e educativo.

Em uma competição, a banca de arbitragem é composta por um grupo de árbitros que avaliam os elementos de dificuldade corporal e outro grupo que analisa a execução da ginasta. As regras de dificuldade (D) se fundamentam no princípio de que, quanto maior o envolvimento de elementos difíceis, mais pontos a atleta terá. No entanto, as regras de execução (E) são regidas pela exigência de que, ao explorar e diversificar os elementos, mesmo que complexos, deve existir o domínio, sendo avaliado o controle corporal tecnicamente bem executado, permeado pela capacidade da ginasta em realizar com facilidade e graciosidade seus movimentos ${ }^{21}$, o que implica em fazer de forma tecnicamente correta.

Torna-se fundamental, na avaliação do desempenho na ginástica, a consideração acerca da capacidade de explorar e dominar o aparelho em todas as possibilidades e se movimentar em um espaço rico e variado, além de se arriscar, ainda que de forma controlada, em todos os planos e direçóes do movimento ${ }^{21}$. Este fator torna implícita a necessidade de variedade, quando se almeja a vitória, portanto, a criatividade pode ser um fator de motivação na busca pela excelência das performances.

Para a arbitragem, a finalidade é ranquear os atletas em ordem de excelência dos seus desempenhos. Isto ocorre por meio de medidas objetivas, respeitandose as regras esportivas da modalidade, de forma neutra, independente e justa ${ }^{21}$.

Como o próprio nome diz, o Código de Pontuação determina uma codificação a ser seguida na atribuiçáo de pontos e define os parâmetros para esse julgamento. Entre as orientaçóes existentes, a originalidade ${ }^{\mathrm{b}}$ é um fator presente nesses documentos como uma característica fundamental e capaz de diferenciar uma ginasta ou sua equipe ${ }^{21}$. Para tanto, é necessária uma constante reorganizaçáo, de modo a adaptar as práticas às exigências e aos contextos.

Por esse motivo, os Códigos são atualizados a cada ciclo olímpico. A versão atual reguladora dos campeonatos de Ginástica Rítmica se refere ao período de 2017-2020. Robin e Santos ${ }^{21}$, a esse respeito, salientam que o Código de Pontuação é um documento que evolui rapidamente, como um "órgão vivo", que sofre constantes modificaçóes, de acordo com o que se observa e se constrói no devir das práticas.

Porém, ainda que a criatividade possa influenciar as avaliaçóes e o julgamento dos árbitros, este não é um quesito ou um critério claramente definido nos códigos e regulamentos. Além disso, a falta de criatividade pode acarretar deduçôes na nota final de uma ginasta ou equipe. Entretanto, não se tem clareza sobre como essa capacidade é percebida, inserida, ou mesmo, avaliada no contexto competitivo dessa 
modalidade, visto que essa perspectiva baseada na visão dos profissionais diretamente envolvidos nesse processo, como árbitros e técnicos, ainda representa uma lacuna na literatura científica, o que justifica o interesse desse estudo. Assim, o objetivo desse estudo foi investigar os parâmetros de julgamento na percepção subjetiva sobre criatividade, na visão de árbitros e técnicos da modalidade Ginástica Rítmica.

\section{Método}

Este estudo ${ }^{a}$, de natureza qualitativa, contemplou a percepção de árbitros e técnicos de Ginástica Rítmica acerca da criatividade no desenvolvimento dessa modalidade, em âmbito competitivo. Esta escolha se pautou na perspectiva de contribuir com reflexóes capazes de ampliar as discussóes sobre as relaçóes existentes entre criatividade, esporte e arbitragem. Para tanto, foi realizada uma pesquisa bibliográfica acerca da temática criatividade e Ginástica Rítmica, em artigos, livros, teses e dissertaçóes, além de uma pesquisa exploratória, realizada por meio da utilização de entrevista semiestruturada como instrumento para coleta de dados.

\section{Procedimentos}

Esta pesquisa foi submetida e aprovada pelo Comitê de Ética e Pesquisa (CEP) do Instituto de Biociências- UNESP, campus de Rio Claro, sob o protocolo número: 084/2013. Inicialmente, foi feito o contato e o convite para participação e aplicaçáo do instrumento (entrevista) por meio das redes sociais, e-mails e telefonemas, além de indicaçóes de representantes da modalidade. Ainda para a seleção dos técnicos, foi realizada uma pesquisa no site da Confederação Brasileira de Ginástica (CBG), buscando identificar as equipes classificadas nas etapas finais dos principais campeonatos ocorridos no país nos últimos 3 anos, ou seja, na vigência do ciclo olímpico de 2013-2016. Dada à grande quantidade de profissionais envolvidos, ambos, técnicos e árbitros, foram selecionados por conveniência.

Os procedimentos éticos para pesquisa com seres humanos foram respeitados. A anuência foi obtida por meio do Termo de Consentimento Livre e Esclarecido (TCLE), os objetivos e métodos da pesquisa previamente esclarecidos aos participantes, sendo assegurada a liberdade de desistência a qualquer momento e a garantia de anonimato das respostas. Ainda, foi dada ciência a todos acerca da possibilidade de futuras publicações em periódicos científicos, como resultado das análises e discussóes geradas a partir das respostas às questóes pertinentes.

\section{Instrumento}

A entrevista semiestruturada foi realizada individualmente previamente agendada em data e horário acordados entre pesquisadora e participantes do estudo. No intuito de apreender a totalidade das informações e melhor analisá-las, as respostas foram gravadas por e posteriormente, transcritas e analisadas pela pesquisadora.

A primeira parte da entrevista visou à caracterização da amostra participante. Já a segunda parte foi composta por questóes abertas e específicas, sendo 09 perguntas dirigidas aos árbitros e outras 09 aos técnicos. Os questionamentos foram elaborados especificamente para este estudo buscando-se oferecer aos participantes, total liberdade de expressão acerca da temática.

Para os árbitros, a finalidade foi instigar respostas que trouxessem os conceitos e parâmetros utilizados por esses participantes no julgamento de aspectos que envolvem a criatividade em uma competição de Ginástica Rítmica. Já para os técnicos, as questóes incidiram, além dos conceitos pessoais sobre e aspectos envolvidos, na importância de se desenvolver essas qualidades no treinamento das ginastas.

\section{Participantes do estudo}

A amostra intencional participante, selecionada por conveniência, foi composta por 14 participantes, sendo 05 árbitros e 09 técnicos de Ginástica Rítmica, os quais aceitaram o convite e se disponibilizaram a participar do estudo. Todos atenderam aos critérios de inclusão estabelecidos para a presente pesquisa, referentes a serem maiores de dezoito anos e terem atuado em competiçóes nacionais, como árbitros ou como técnicos responsáveis pelo treinamento de atletas e elaboração de suas rotinas e coreografias para concorrerem em eventos ocorridos na vigência do ciclo olímpico 2013 a 2016.

Quanto aos 05 árbitros participantes dessa pesquisa, aqui denominados como AGR, 03 eram do sexo feminino e 02 do sexo masculino, faixa 
etária entre 23 e 46 anos, experiência de 04 a 22 anos em arbitrarem de eventos competitivos de Ginástica Rítmica, todos, árbitros nacionais e $01 \mathrm{com}$ credenciamento inclusive em arbitragem internacional. Já dos 09 técnicos (TGR), 07 eram do sexo feminino e 02 do sexo masculino, apresentando idades de 23 a 46 anos e tempo de prática no treinamento de atletas e elaboração de rotinas para diversas competiçôes de Ginástica Rítmica de 06 a 20 anos.

Vale salientar que, tanto os árbitros participantes (AGR), como os técnicos (TGR), apresentaram vasta experiência com a modalidade Ginástica, inclusive como atletas. Além disso, os 05 árbitros eram também experientes no treinamento de atletas da modalidade foco desse estudo e 03 dos técnicos atuam com equipes e ginastas tidas como referência pelas conquistas e visibilidade no âmbito de suas participaçôes. Entre os participantes, o total dessa amostra apresentou formação em Educação Física, sendo 06 com pós-graduação completa: 01 árbitro com formação em níveis de doutorado, mestrado e especialização, outro árbitro com especialização, 01 técnico com mestrado e outros 03 técnicos com especialização.

Para este estudo, o árbitro é o profissional a quem é firmada a responsabilidade de julgar o desempenho das atletas em um evento competitivo de GR, cabendo a ele a atribuição de notas que traduzam a forma como avalia e percebe o desempenho das atletas ginastas. Já o técnico, se refere ao profissional responsável por ensinar, treinar, elaborar as rotinas e coreografar as séries, zelando e orientando as condutas, em prol do atendimento aos fundamentos técnicos e regulamentos vigentes para as competiçóes de GR.

\section{Análise dos dados}

A análise dos dados foi feita por meio da Técnica de Análise de Conteúdo, conforme proposto por BARDin ${ }^{22}$. Esta é uma técnica que busca favorecer a correta interpretação do que foi dito pelos participantes e que permite ao pesquisador, classificar esse resultado em temas ou categorias de forma a melhor compreender o teor dos discursos ${ }^{23}$. Para tanto, se procedeu à criação de categorias temáticas as quais corresponderam às características ou significados dos conteúdos pertinentes às respostas obtidas.

Nesta etapa da pesquisa foi utilizado o $\mathrm{Aquad}^{7}$, um software para análise de pesquisa qualitativa ${ }^{24}$ que facilitou a organização das hipóteses, a identificação das unidades de significado, e do que foi mais recorrente nas respostas dos árbitros e técnicos. Após reduzir, codificar e, assim, chegar à categorização dos dados, os aspectos considerados semelhantes foram agrupados de acordo com a sua pertinência e com a possibilidade de enriquecer discussóes acerca dessa temática e dessa forma, atender ao objetivo proposto para esse estudo. Para o tratamento, inferência e interpretação dos resultados foram organizadas duas Categorias Temáticas, uma referente aos Conceitos e aspectos relacionados, e outra relativa à Avaliação da criatividade.

\section{Resultados}

\section{Conceitos de criatividade na ginástica rítmica}

No intuito de apreender a percepção de árbitros e técnicos de Ginástica Rítmica, participantes desse estudo, acerca do que criatividade representa para o desenvolvimento dessa modalidade, bem como, quais são os aspectos que se relacionam a essa capacidade, para compor esta categoria, foram consideradas as respostas para as seguintes questóes:

\section{Para os árbitros (AGR)}

- Para você, o que é criatividade em uma performance na modalidade Ginástica Rítmica?

- Você percebe alguma relação entre criatividade e desempenho?

- Em que aspectos, além das orientaçóes existentes, você se apoia para julgar se uma apresentação é criativa?

- Existe algum aspecto da apresentação no qual o uso da criatividade fique mais evidente?

\section{Para os técnicos (TGR)}

- Para você, o que é criatividade em uma performance na modalidade Ginástica Rítmica?

- Você percebe alguma relação entre criatividade e desempenho?

- Que aspectos você busca melhorar na performance da atleta, para que os movimentos se 
Fonte: Trevisan PRTC. Criatividade motora na Dança Esportiva e na Ginástica Rítmica: percepção subjetiva de técnicos e árbitros [tese]. Rio Claro (SP): Universidade Estadual Paulista; 2016.

\section{tornem criativos?}

Dessa forma, de acordo com os técnicos e árbitros entrevistados para esse estudo, criatividade se refere a uma capacidade que envolve qualidades diversas conforme indicado no QUADRO 1.

\section{QUADRO 1- Conceitos para criatividade.}

\begin{tabular}{|c|c|c|}
\hline Respostas & AGR & TGR \\
\hline $\begin{array}{l}\text { É a composição coreográfica, uma série elaborada com } \\
\text { contexto de forma que atenda às exigências. }\end{array}$ & $1,2,3,4,5$ & $1,2,3,4,5,6,7,8,9$ \\
\hline Criar coisas novas, diferentes. & $1,2,4,5$ & $1,2,5,6,7,8,9$ \\
\hline Uma forma única, não comum e inovadora de criar. & $1,2,4,5$ & $1,2,5,6,7,8,9$ \\
\hline Inovar, fazer o que ninguém fez e, portanto, se diferenciar. & $1,2,4,5$ & $1,2,5,6,7,8,9$ \\
\hline $\begin{array}{l}\text { Executar os passos de dança transpassando a ideia da } \\
\text { coreografia. }\end{array}$ & $2,3,5$ & $2,3,4,5,6,7,8,9$ \\
\hline $\begin{array}{l}\text { É a expressáo corporal da ginasta relacionada ao contexto } \\
\text { da série e da música. }\end{array}$ & $2,3,4,5$ & $2,4,5,6,7,8,9$ \\
\hline Saber usar os critérios para aumentar a nota. & $1,2,3,4,5$ & $1,2,4,5,7$ \\
\hline O que agrada ao árbitro e ao público. & $2,3,4,5$ & $2,3,4,5,7$ \\
\hline $\begin{array}{l}\text { Conseguir expressar uma ideia, uma proposta de maneira } \\
\text { harmoniosa. }\end{array}$ & $2,3,4,5$ & $4,5,6,7,9$ \\
\hline É algo que relaciona a série, ao ritmo da música. & $3,4,5$ & $4,5,6,8$ \\
\hline $\begin{array}{l}\text { O que flui e se encaixa na série, o que liga um movimento } \\
\text { ao outro de forma inovadora. }\end{array}$ & $2,3,4$ & $2,3,4,7$ \\
\hline O que tem começo meio, fim e contexto. & $2,3,4$ & $2,3,4,7$ \\
\hline É o que chama a atenção. & $2,3,4$ & $2,3,4,7$ \\
\hline O que transmite o que a ginasta é. & $2,3,4$ & $4,7,8$ \\
\hline Algo que transmite o que é de valor. & $2,3,4$ & $4,7,8$ \\
\hline $\begin{array}{l}\text { É um processo de autodescobrimento tanto do técnico } \\
\text { como da ginasta. }\end{array}$ & $2,3,4$ & $4,7,8$ \\
\hline O que é bonito e maravilhoso. & 2,4 & $2,7,8,9$ \\
\hline É o artístico da série. & 3 & $2,4,8$ \\
\hline $\begin{array}{l}\text { Apresentar variedade no uso dos elementos corporais e no } \\
\text { deslocamento no espaço. }\end{array}$ & 2,3 & 4,7 \\
\hline Um todo difícil de isolar. & 2 & $2,6,7$ \\
\hline $\begin{array}{l}\text { Uma forma de explorar e conseguir utilizar todas as capa- } \\
\text { cidades do atleta. }\end{array}$ & 2 & $2,6,7$ \\
\hline $\begin{array}{l}\text { O que apresenta um sentimento estético, tornando-se } \\
\text { uma forma de buscar o que se sente. }\end{array}$ & 2 & 7,8 \\
\hline $\begin{array}{l}\text { Transcender, ultrapassar, ir além dos limites da rotina ou } \\
\text { do que é usado para o controle do aparelho, do corpo. }\end{array}$ & 2 & 7,8 \\
\hline
\end{tabular}


Diferentes aspectos salientam a percepção e o entendimento desses árbitros e técnicos acerca da criatividade no contexto da Ginástica Rítmica.
Esses fatores foram agrupados em subcategorias e se relacionam à criatividade, conforme demonstrado na FIGURA 1.

FIGURA 1 - Aspectos relacionados aos conceitos de criatividade para árbitros e técnicos de GR.

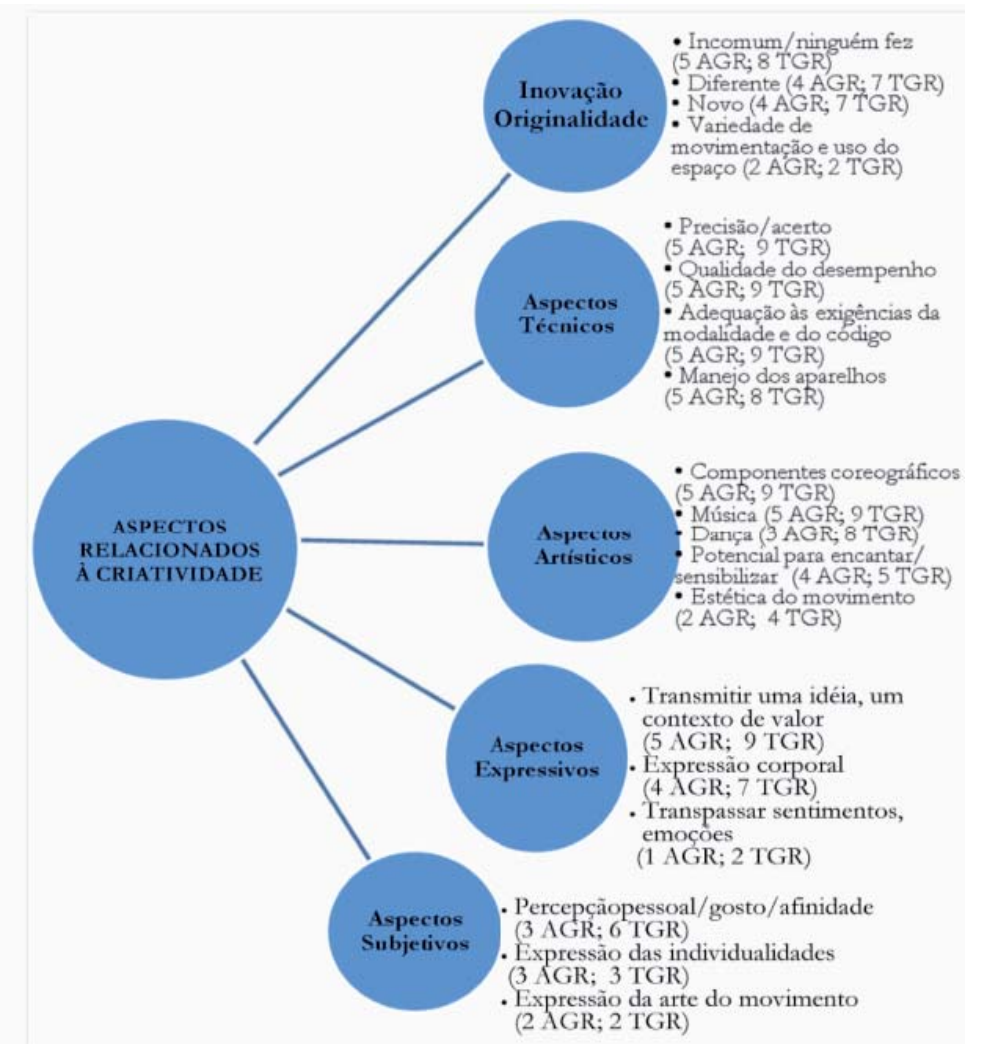

Fonte: Trevisan PRTC. Criatividade motora na Dança Esportiva e na Ginástica Rítmica: percepção subjetiva de técnicos e árbitros [tese]. Rio Claro (SP): Universidade Estadual Paulista; 2016.

\section{Avaliaçáo e percepção da criatividade}

Nesta categoria, foram agrupadas as respostas que evidenciaram o julgamento da criatividade, no que tange ao treinamento e ao contexto competitivo de Ginástica Rítmica. Para tanto, as questóes utilizadas foram as seguintes:

\section{Para os árbitros (AGR)}

- A criatividade é um item importante na avaliação? Por quê?

- A criatividade está incluída nos formulários de avaliação de sua modalidade esportiva?

- Existe alguma forma de orientação, norma ou explicação nos regulamentos, sobre como julgar o item criatividade em uma apresentação?

- Os participantes considerados mais criativos são os que apresentam os melhores desempenhos?

\section{Para os técnicos (TGR)}

- A criatividade é um item importante na elaboração das rotinas/coreografias? Por quê?

- A criatividade está incluída nos formulários de avaliação de sua modalidade esportiva?

- Existe algum momento mais propício para utilizar a criatividade no treinamento?

- Para você, o uso da criatividade auxilia o desempenho ou a qualidade do movimento?

A importância da criatividade foi ressaltada, especialmente entre atletas de níveis mais avançados, podendo vir a auxiliar o desempenho de uma equipe ou de uma ginasta se utilizada adequadamente. Dessa forma, o uso da criatividade enriquece a rotina 
de que essa criatividade representa uma forma diferenciada de expressar ideias, sentimentos e emoçóes, por meio da motricidade humana. Essa autora salienta que os movimentos corporais podem ser o resultado de uma capacidade de pensar e agir para construir novos conhecimentos, os quais são expressos por meio de uma coreografia de dança, na elaboração e apresentação de uma série de ginástica, de um novo jogo, uma nova maneira de brincar, ou seja, por meio de uma nova ação, o que é descrito pela autora como criatividade motora.

Para 04 árbitros (AGR 1, 2, 4, 5) e 07 técnicos (TGR 1, 2, 5, 6, 7, 8, 9), criar é fazer coisas diferentes e incomuns. É uma forma inovadora de fazer o que ninguém fez e, assim, se diferenciar. Pessoas criativas buscam solucionar problemas utilizando diferentes estratégias, e assim, desempenham uma atividade com base na inovação, o que também se aplica a performances artísticas e atléticas.

Para Mohamed ${ }^{14}$, este é um processo que resulta da habilidade para pensar, renovar e dar novas ideias, o que favorece o desenvolvimento de habilidades criativas de forma a revisitar experiências anteriores e aplicar rapidamente os conhecimentos adquiridos ao contexto, o que a partir das atividades físicas relocam informaçóes e habilidades a serem transpostas na performance.

Este também foi um dado encontrado nas respostas que abordaram os conceitos que esses indivíduos têm acerca da temática criatividade. Para todos, criatividade é também aquilo que é percebido como uma forma de se adequar ao contexto, à música, à coreografia e ressaltar as características pessoais da ginasta.

Essa criatividade motora se constitui em uma propriedade singular humana, tendo a originalidade, a fluência, a flexibilidade e a extensão/ expansão, como fatores que caracterizam esse processo. Representa uma forma de criar o novo, demonstrando habilidades em se apropriar do contexto e lidar com as dificuldades por meio dos movimentos corporais ${ }^{14}$.

A originalidade é para MoHAmed ${ }^{14}$ a habilidade para produzir o que não reproduz aquilo que é comum. Para WeChSLER ${ }^{25}$ é a habilidade de produzir ideias raras. A flexibilidade, segundo essa autora ${ }^{25}$, é o que se refere à capacidade de apresentar diferentes ideias, incluindo as tentativas de solucionar um problema. A fluência é a capacidade de produzir grande quantidade de açóes válidas que possam ser percebidas por sua relevância. Já a extensão ou expansão, diz respeito a não se restringir ao que existe, representando o potencial em transpor paradigmas e ultrapassar limites ${ }^{5,25}$.

A inovação e a originalidade dos movimentos, seja quanto ao uso/manejo dos aparelhos (fita, bola, arco, maça, corda), quanto na composição da série ou coreografia, foram aspectos relevantes descritos nas respostas, tanto de árbitros (AGR), como dos técnicos (TGR). Essas relaçóes puderam ser evidenciadas por meio das associaçóes feitas com termos como incomum/ninguém fez (5 AGR; 8 TGR), diferente (4 AGR; 7 TGR), novo (4 AGR; 7 TGR), variedade de movimentação e uso do espaço (2 AGR; 2 TGR). Para o AGR 1 e para o TGR 1, apresentar a originalidade significa fazer o extraordinário e o que ninguém fez.

A originalidade se torna um fator relevante no caso dos esportes por meio do movimento corporal, sendo o que caracteriza a criatividade especialmente quando adicionada à fluência, flexibilidade e extensão motora aplicadas à performance ginástica. Outras características são elencadas nos estudos de WECHSLER et al. ${ }^{5}$ e puderam ser evidenciadas nas respostas desses participantes: Emoçáo: habilidade para expressar sentimentos e se emocionar. Fantasia: a representação de algo imaginário. Movimento: a construção da dinâmica das açôes. Perspectiva Incomum: apresentar aspectos raros e diferentes. Perspectiva Interna: representar o que está oculto, o que é significante ao indivíduo. Uso de Contextos: preocupação em criar o que é adequado ao ambiente. Combinaçáo: a síntese de ideias. Extensáo de Limites: potencial para transpor paradigmas, ultrapassar limites, ir além das restriçóes existentes. Títulos Expressivos: expressar uma ideia, algo percebido por seu valor. Elaboraçáo: os detalhes que compóem e enriquecem uma ação na articulaçấo das ideias e conhecimentos. O QUADRO 2 ilustra a presença dessas características nos conceitos que árbitros e técnicos descreveram para criatividade.

Por meio desses apontamentos pode-se evidenciar, nessa pesquisa, que os conceitos acerca da temática criatividade, além da originalidade e inovação, para esses participantes, estiveram relacionados a diversos aspectos. Entre eles, podem-se citar os técnicos, artísticos, expressivos e subjetivos. Diferentes possibilidades de criação estiveram presentes na composição e elaboração das coreografias, para todos os árbitros e técnicos. No planejamento das coreografias incluem-se o ritmo proposto para o controle dos aparelhos típicos da modalidade GR, bem como, o uso da música, os quais, ao serem associados, se transformam em uma sequência de movimentos corporais que contribuem para o processo criativo. 
QUADRO 2 - Características para os conceitos para criatividade.

Fonte: Trevisan PRTC. Criatividade motora na Dança Esportiva e na Ginástica Rítmica: percepção subjetiva de técnicos e árbitros [tese]. Rio Claro (SP): Universidade Estadual Paulista; 2016.

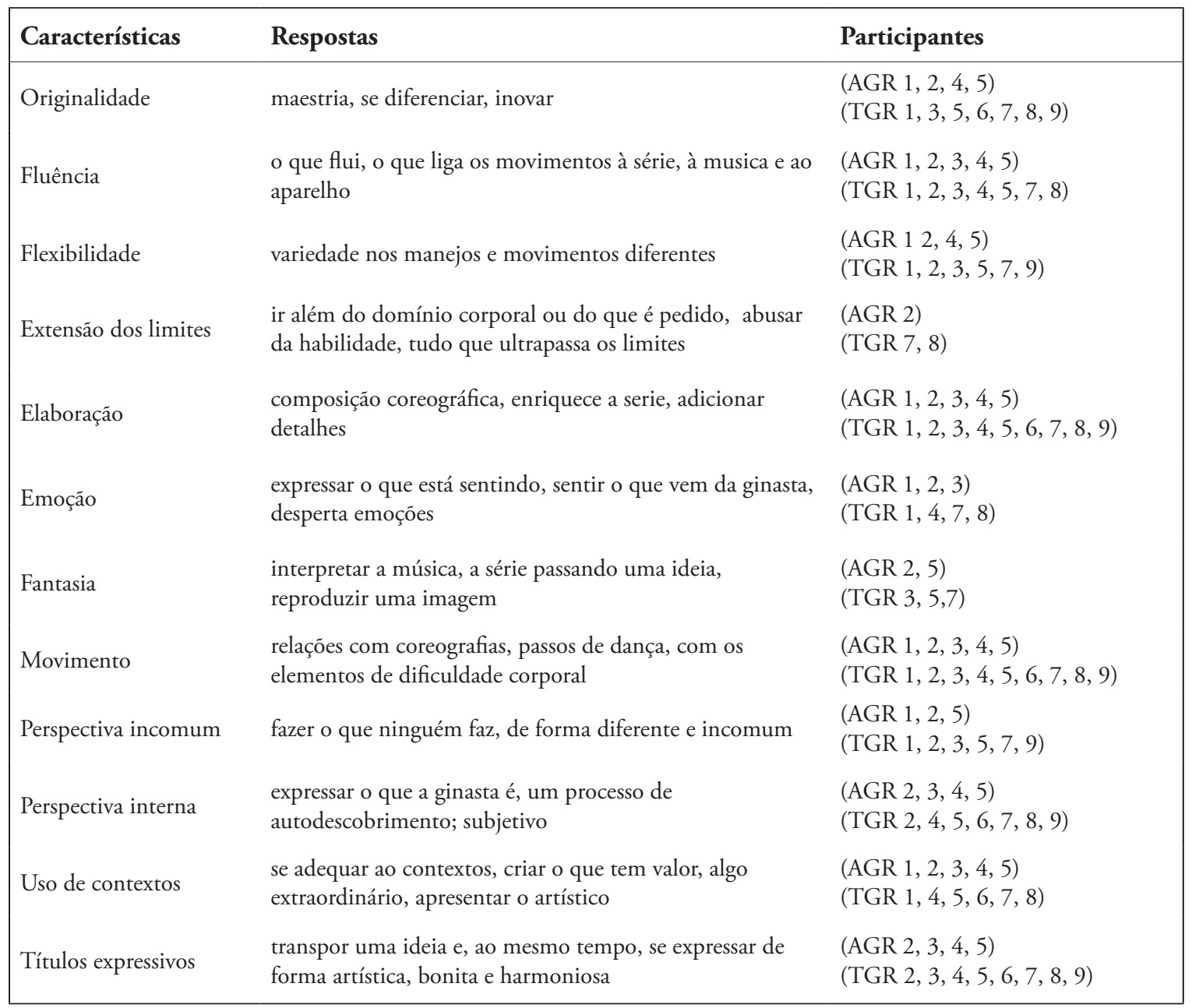

A esse processo criativo, quando este se refere às atividades motoras, incluindo aqui a GR, devem ser adicionadas ações de valor artístico, no planejamento das coreografias, no controle dos movimentos, no uso da música, o que foi de igual modo, expresso nas respostas, tanto dos árbitros (AGR 2, 3, 4, 5), como dos técnicos entrevistados para esta pesquisa (TGR 2, 4, 5, 6, 7, 8, 9). Para 04 árbitros (AGR 2, 3, 4, 5) e 07 técnicos (TGR 2, $4,5,6,7,8,9)$, a criatividade é o algo a mais que relaciona a expressão corporal da ginasta ao contexto da série e da música.

Os exercícios feitos de forma rítmica contribuem para a criação do que é novo. Nesse contexto, a implicação do ritmo é um princípio constituinte que se vale do potencial criativo para acontecer. A construçâo das ideias e do novo amplia o repertório motor da atleta, sendo que o ritmo da performance requer qualidades específicas no desempenho da ginasta, para que ela obtenha sucesso em sua apresentaçấo ${ }^{14}$.

A GR é uma modalidade que, de acordo com Boaventura $^{27}$ e Pereira $^{28}$, tem suas singularidades permeadas pela síntese de elementos entrelaçados pela técnica apurada, pelo valor estético, pela leveza, pelo acompanhamento musical, pelo ritmo e dinâmica de danças diversas, por elementos acrobáticos e pela manipulação de objetos, o que remete a uma expressão artística e técnicas específicas e que lhes são próprias. Assim, utilizar corretamente os movimentos e as regras existentes desde o treinamento, bem como, criar coisas diferentes, com um estilo diferenciado, de forma única, não comum e inovadora, envolve o processo criativo, tanto da ginasta, como do seu técnico. Criatividade, para 04 árbitros e 07 técnicos, é inovar, fazer o que ninguém fez e, portanto, se diferenciar 
(AGR 1, 2, 4, 5; TGR 1, 2, 5, 6, 7, 8, 9).

Essa criação acontece essencialmente na elaboração da série, atrelada ao atendimento das exigências para todos os entrevistados, o que corresponde à composição, sendo que, segundo CAVAlCANTI $^{29}$, corresponde à coreografia criada para a ginasta apresentar na competição, ou seja, a sequência de movimentos ginásticos, incluindo o uso dos aparelhos, acompanhados por uma música selecionada para atender ao contexto desejado.

Esses apontamentos indicam que, para esses participantes, o processo criativo se desenvolve no âmbito do treinamento da ginasta, na combinação dos elementos que irão compor sua apresentação, instigando reflexôes acerca das estratégias e decisóes metodológicas que permeiam as pedagogias adotadas. Contudo, por meio das respostas obtidas pela entrevista para as questóes referentes a essa categoria acerca dos conceitos sobre criatividade na GR, puderam ser evidenciados aspectos técnicos, artísticos e expressivos, os quais se mostraram primordiais para o desenvolvimento da modalidade, o que demonstra que, nesse processo, a coreografia apresentada se torna o resultado, não só do que é criado pelo técnico. Ao executar a série, existem composiçóes de outros elementos que a ginasta traz como produto da sua aprendizagem, da sua individualidade, da forma como apreendeu e entendeu os movimentos propostos.

Aspectos técnicos alinhados com a precisão, acerto, qualidade do desempenho, adequação às exigências da modalidade e do Código, foram salientados por todos os participantes. A criatividade foi associada ao manejo dos aparelhos (AGR 1, 2, 3, 4, 5; TGR 1, 2, 3, 4, 5, 7, 8,9 ). Saber usar os critérios para aumentar a nota (AGR 1, 2, 3, 4, 5; TGR 1, 2, 4, 5, 7) conseguir executar os elementos corporais, associando a técnica corporal e de aparelho à música, ao artístico e à expressividade, foram formas descritas como uma maneira de se trabalhar criativamente os movimentos gímnicos. Para 01 árbitro (AGR 2) e 02 técnicos (TGR 7, 8), criar envolve a capacidade de transcender, ultrapassar limites, ir além do controle do aparelho e do controle do corpo para a execução dos elementos corporais, sejam eles fundamentais, obrigatórios ou não.

Esses elementos corporais se referem a qualquer movimento intencional, como parte de uma série ou exercício de $\mathrm{GR}^{29}$. O Código de Pontuaçấo traz a relação de movimentos que devem caracterizar os movimentos gímnicos da GR, os quais estâo organizados em elementos dos Grupos Técnicos Fundamentais específicos para cada aparelho e
Outros Grupos Técnicos, sendo que ambos estão compreendidos como dificuldades corporais relativas aos saltos, equilíbrios, rotaçóes, combinaçóes dos passos de dança, elementos pré-acrobáticos e outros. Além disso, devem estar coordenados com o manejo dos aparelhos, incluindo quicadas, lançamentos, recuperação do aparelho, rolamentos pelo solo, circunduçōes, balanceios, flexibilidade, movimentos de ondas, etc. ${ }^{30}$.

As decisões quanto às sequências de movimentos podem contribuir para tornar as composiçóes significativas, mas, para que isso seja percebido, é necessária a habilidade para moldar as qualidades do movimento, o que ocorre como um resultado da sensibilidade da ginasta em usar dinâmicas precisas e forças apropriadas. Estas qualidades resultam em utilizar cada parte do corpo em movimento, por meio de um jogo entre contração e relaxamento, queda e recuperação, justamente para produzir um movimento suave, mostrar uma qualidade especial, aplicar força muscular como uma forma única de combinar e variar as qualidades do movimento corporal, dinâmicas que irão revelar suas sutilezas expressivas ${ }^{31}$.

$\mathrm{Na}$ GR, é requerido um alto grau de habilidades físicas, técnicas e psicológicas, para a obtenção de uma execuçáo perfeita dos movimentos corporais associados ao controle dos aparelhos bola, fita, arco, maças, corda ${ }^{31}$. Todos esses elementos, centrados na apropriaçáo de técnicas corporais e de aparelho, são permeados por componentes em que o desempenho artístico diz respeito à capacidade de transformar uma composição tecnicamente estruturada, em uma performance expressiva, com boa interpretação e musicalidade ${ }^{20}$.

Nessa dimensão artística, a criatividade é uma capacidade que se torna evidente, por meio do controle motor e da execução harmônica dos movimentos ${ }^{31}$. Entre os entrevistados, o artístico da série nada mais é do que a criatividade da série (AGR 3; TGR 2,4, 8). Para a TGR 8, a criatividade na GR simboliza "uma obra de arte".

Aliado a esse valor artístico, está a percepção estética do que é bonito, harmonioso, do que agrada e sensibiliza, não só pela qualidade, mas também, pelo valor do que é transmitido e comunicado por meio da performance. Assim, os aspectos expressivos, os quais também apresentam um cunho subjetivo na visão desses indivíduos, representam um diferencial e podem fazer com que essa ginasta se torne uma referência pela excelência com que desempenha os movimentos ginásticos.

Para esses participantes, a beleza e a harmonia 
dessas combinaçóes criativas (AGR 2, 4; TGR 2, $7,8,9$ ) são fatores que fazem da ginasta e sua série uma referência nesse esporte, especialmente quando associadas à exatidão e perfeição do movimento. Para uma das técnicas, as séries ginásticas precisam ser dinâmicas e estar artisticamente dentro da música e no contexto escolhidos para a atleta, sendo, a criatividade, "o maior coadjuvante das rotinas" (TGR 6). Esse envolvimento com as músicas foi descrito por 11 participantes (AGR 2, 3, 5; TGR 2, 3, 4, 5, 6, 7, 8, 9). Ainda, essa percepção do que é criativo e artístico apresenta o potencial para encantar/sensibilizar (AGR 2, 3, 4, 5; TGR 2, 3, 4, 5, 7) e se relaciona à estética do movimento (AGR 3, 5; TGR 2, 4, 5, 8).

A GR é um esporte de natureza artística ${ }^{17,31}$. Dessa forma, esses autores, de igual modo aos participantes desse estudo, destacam a relevância da música e dos passos de dança, ambos atrelados à composição artística de uma apresentação ginástica.

O belo promove o espetáculo esportivo e expande a percepção da experiência estética, o que significa um estado vertiginoso construído por meio da fruição de um novo fazer, que se refaz na relação tensa entre razão e emoção, dor e prazer, contenção e vazão e que remete a um teor emocional. Ainda, ao se considerar o contexto competitivo de um esporte, na maioria das modalidades, uma emoçáo acontece para além da representaçáo e se torna uma possibilidade para se transitar entre o que é real e imaginário, entre o que é objetivo e o que é subjetivo ${ }^{32}$.

Toledo e Antualpa ${ }^{17}$ destacam que o principal objetivo de um componente artístico é trazer emoção e a ideia de expressão, o que, na GR, é traduzido pelo acompanhamento musical e pela expressividade. A expressão corporal da ginasta tem a participação de todos os segmentos corporais em movimento, combinados à sua expressão facial, que deve comunicar um tema, de igual modo acertado nas nuances da música e a uma mensagem transmitida pela composição coreográfica. Para todos, isto também descrito nas respostas para este estudo, o uso da criatividade é associado como uma forma de a ginasta expressar uma ideia de valor. Ainda, transpassar a proposta que tem, com a ideia da série guiada pela música utilizada, é expressar o que tem um contexto de harmonia, de expressão corporal, de expressão facial (AGR 2, 3, 4, 5; TGR 2, 4, 5, 6, 7, 8, 9).

Para Ávila-CARVALHO ${ }^{20}$, os movimentos entre atletas de alto rendimento permitem a expressão de sentimentos, aspecto que também foi relatado por 01 árbitra e 02 técnicas (AGR 3; TGR 4, 8). No entanto, para Ávila-CARVALHO ${ }^{20}$ é preciso encontrar uma força criativa capaz de gerar composiçôes excepcionais, no intuito de gerar novas perspectivas de movimento. Contudo, também para este estudo, ressalta-se a presença da subjetividade, em se tratando da percepção do que é criativo.

Beleza, eficácia, apreciação, estética, a interpretação do que é artístico, bem como, a percepção do que é visto em uma performance, possuem um cunho subjetivo. Inclusive, o que é considerado novo, diferente, original, extraordinário e incomum, pode variar de pessoa para pessoa, devido à afinidade, experiência e ao próprio conceito que um indivíduo tem a respeito de determinado conhecimento ${ }^{20}$. Assim, aspectos subjetivos foram salientados por meio de respostas que reforçaram que o criativo se refere à percepção pessoal, ao gosto, à afinidade com o que está presente na apresentação da ginasta (AGR 3, 4, 5; TGR 2, 4, 5, 6, $8,9)$, englobando a expressão das individualidades (AGR 2, 3, 4; TGR 4,7, 8) e a expressão da arte do movimento (AGR 3, 5; TGR 4, 5). Nesse sentido, uma das técnicas reforça essa percepção subjetiva, ao afirmar que: "o que é extraordinário pra você não é pra mim."(TGR 9).

De igual modo, Huggins ${ }^{33}$ destaca a existência de um olhar subjetivo para o julgamento do que é considerado ou não uma performance padrão. Especialmente em se tratando de habilidades altamente especializadas e em modalidades que expressam uma forma de arte, como a ginástica, em que a estética se torna um fator essencial ${ }^{33}$, essa complexidade se torna evidente quando se identifica a variedade de formas de interpretar e perceber os movimentos ginásticos, o que depende de como são percebidos. Para esse autor, esse olhar esportivo pode ser baseado na autoidentidade, na leitura e no conhecimento que o indivíduo tem, o que implica em uma percepção subjetiva, não só sobre esse esporte, mas também, acerca do todo apresentado, o que, inclusive, se torna um elemento gerador de divergências na avaliação da ginasta.

Também Debien $^{34}$ e Bortoleto ${ }^{35}$, ainda que este se refira à Ginástica Artística, de igual modo ao presente estudo, defendem a presença da subjetividade como um fator preponderante no julgamento de competiçóes de GR, até mesmo por ser esta uma modalidade esportiva que náo dispóe de um sistema que possa ser automático ou direto nas formas de medir o rendimento da atleta, destacando, ainda, que os próprios árbitros passam por situações de stress, as quais podem interferir no momento da avaliação. Essas questões referentes ao julgamento de ginastas, focalizando a criatividade, compóem a próxima categoria de análise para esse estudo. 


\section{Avaliação da criatividade}

Este estudo salienta a importância da análise e da interpretação de conceitos e parâmetros utilizados para o julgamento do que é percebido como criativo, em uma competição de GR. Essa é uma modalidade que requer o uso de qualidades artísticas e expressivas, sobre as quais convergem subjetividades intrínsecas no que a ginasta apresenta e nas formas de avaliação e que, ao mesmo tempo, são permeadas por conhecimentos e exigências técnicas específicas, estabelecidas por códigos e regulamentos determinados pelas federações responsáveis por essa modalidade.

$\mathrm{Na}$ organização dos elementos e movimentos que irão compor uma apresentação de GR, o uso do potencial criativo se torna uma prerrogativa, inclusive citada pelos entrevistados, seja na apresentaçáo da ginasta, como na composição da coreografia elaborada pelo técnico a ser apresentada por uma atleta em um contexto competitivo. Ainda, a reprodução de performances e a falta de variedade na movimentação são fatores desencorajados nos Códigos de Pontuação que regem essa participação e acabam por ser motivo de desvalorização na pontuação de uma equipe ou de uma ginasta.

Nessa categoria de análise salientou-se quando, como acontece e quais as orientaçóes existentes, bem como, a importância da criatividade no julgamento de ginastas de GR em contextos competitivos. Tanto para os árbitros, como para os técnicos, as ginastas de níveis mais avançados são as que melhor contextualizam o que é novo e diferente em suas performances, colocando, em seus movimentos uma forma única de se expressarem, sendo que por apresentarem maior domínio corporal e controle do aparelho se arriscam mais na combinaçấo de elementos corporais (5 AGR; TGR 1, 4, 5, 6, 7,8). Para o AGR 2 e para o TGR 7, é com estas atletas que o técnico pode "abusar" da sua criatividade.

Entretanto, ainda que as consideradas atletas mais criativas sejam as de níveis mais avançados, foi destacada, especialmente nas respostas dos técnicos, a necessidade de um olhar cuidadoso acerca desse aspecto já na iniciação esportiva dessas atletas. Isso corrobora a literatura, na qual se aponta a importância do trabalho com crianças no desenvolvimento da criatividade ${ }^{2,4}$.

Contudo, conforme salientado por todos os participantes, a palavra criatividade propriamente dita não está incluída nos formulários de avaliação no Código de Pontuação.
As orientaçôes existentes no Código de Pontuação e nos regulamentos específicos das competiçóes salientam a obrigatoriedade de variedade. Dessa forma, a elaboração de séries que contenham movimentos repetidos em sua construção é desestimulada e a originalidadeé valorizada, ao serem sinalizadas deduçóes nas notas das ginastas caso uma dificuldade corporal seja apresentada mais de uma vez, ou não apresente combinaçóes de diferentes elementos pertinentes ao Grupo técnico fundamental ou ao Outro Grupo, por formas diferenciadas.

O Código determina que tudo que é feito pela ginasta tem que ser perfeito (AGR 2; TGR 7), mas, quando náo há variedade no uso dos elementos corporais, há uma despontuação, sendo acrescentadas bonificaçôes na nota da ginasta quando ela apresenta movimentos diferentes julgados como adequados e criativos, os quais enriquecem sua série (AGR 1, 2, 3, 4, 5; TGR 1, $2,3,4,5,6,7)$. Ainda que primeiramente sejam avaliados, a técnica de ginástica, o trabalho corporal, o trabalho com o aparelho, conforme afirmado pelo AGR 2, ou que seja, priorizado o melhor rendimento corporal na nota da atleta, como ressaltado nas respostas da TGR 9, a atleta será "despontuada", ou seja, sofrerá deduçôes em suas notas, caso a série apresente elementos repetitivos (AGR 2, 4; TGR 3, 7). "O próprio Código de Pontuação exige isso.” (TGR 3).

Em competiçóes de GR, existem 02 grupos distintos de árbitros: um para julgar o quesito Dificuldade (D), que avalia as dificuldades corporais (saltos, equilíbrios, elementos de rotação, passos de dança, lançamentos dos aparelhos, etc.) e outro, para a Execução (E), o qual analisa tanto as falhas artísticas relacionadas à expressividade, musicalidade, organização, variedade dos movimentos, utilização do espaço, como as falhas técnicas que se referem aos erros cometidos pela ginasta no momento da sua apresentação em uma competição $\mathrm{o}^{30,36}$. Entre os 05 AGR, a criatividade acaba sendo percebida, tanto na Avaliação de Dificuldade, quanto de Execução, pois é contemplada em toda a composição da série e na performance artística da atleta, por meio da harmonia dos movimentos, da interpretação do que foi proposto e pela qualidade com que esta ginasta se expressa. A utilização variada de elementos de dificuldade corporal, na combinaçáo dos passos de dança, nos lançamentos, nas recepçóes, no manejo dos aparelhos de uma forma associada à beleza e à perfeição dos movimentos, foram fatores que ilustraram essas respostas.

De igual modo, elementos avaliados tanto pela banca 
de Dificuldade, como de Execução, foram citados por 06 técnicos (TGR 1, 3, 4, 5, 6, 7). A criatividade é também julgada na composição da série para 08 técnicos (TGR 1, 2, 3, 4, 5, 7, 8, 9), assim como um componente artístico (TGR 1, 2, 4, 5, 6, 7, 8, 9). É encorajado apresentar um "todo coesivo", o qual envolve originalidade, execuçáo perfeita, beleza e dificuldade (AGR 1), os árbitros irão recorrer à "composição como um todo" no julgamento da performance. (AGR 2).

A GR é caracterizada por revelar, na composição de uma série, qualidades associadas à beleza e à graciosidade dos movimentos ginásticos. SANTOS et al..$^{37}$ destacam que, entre os diversos estudos existentes, essa modalidade se diferencia por combinar arte aos gestos de alta complexidade, os quais, executados com aparelhos ou não, requerem o desenvolvimento apurado da coordenação motora, resistência muscular, agilidade, flexibilidade, força, equilíbrio, destreza, aliados à perfeição técnica da execução de movimentos.

Juntas, estas qualidades, conjugadas com a manipulação dos aparelhos específicos da modalidade, se traduzem em movimentos criativos, precisos e de alta complexidade que para apresentar diferentes formas de controlar a técnica corporal e o aparelho se configuram como componentes artísticos da série ${ }^{36,38}$. Este envolvimento, especialmente com o que é percebido como criativo, é avaliado subjetivamente para 04 participantes (AGR 3, 5; TGR 4, 5) e, ainda, se relaciona ao artístico: "esse artístico nada mais é do que a criatividade da série" (AGR 3; TGR 4).

No Código referente ao ciclo 2013-2016, houve um aumento da apreciação dos aspectos artísticos, o que Toledo e Antualpa ${ }^{17}$ ressaltam como um fator que valoriza as especificidades da GR e um avanço para esse esporte, pois, para elas, essas são características das origens dessa modalidade que não podem ser esquecidas e nem deixadas de lado em um contexto competitivo. Este artístico está na execução, segundo o AGR 5 e o TGR 5. De acordo com DeBIEN ${ }^{34}$, é responsabilidade da banca de Execução avaliar, não só as faltas técnicas, mas também, as artísticas, conforme descrito inclusive no Código 2013-2016 ${ }^{30}$.

A avaliação dos aspectos artísticos envolve unidade de composiçáo, as relaçóes da música com o movimento, o uso do espaço, o que se tornou responsabilidade do júri de execução ${ }^{17}$. De igual modo, para a TGR 2, a criatividade é percebida na composição da série, na relação música-movimento, na expressáo corporal da ginasta, na utilizaçáo do espaço. Portanto, é avaliada, mesmo que indiretamente, na execução.

Vale ressaltar que, no Código de Pontuação de 2013-2016, o artístico era julgado juntamente com a execução técnica. No entanto, o Código atual, o qual rege o ciclo 2017-2020, apesar de fazer parte da banca de execuçáo, o quesito das faltas artísticas passou a ser avaliado por árbitros que o julgam separadamente das faltas técnicas ${ }^{39}$. Essa revisão e modificação na forma de avaliar o artístico da série, no atual Código de Pontuação, reforça o reconhecimento da importância do julgamento desses aspectos. Outros contextos foram citados nas entrevistas, como uma forma de orientar a percepção do que é criativo em uma performance de GR. A própria elaboração da série, um movimento ligado ao outro, foi apontada pelos AGR 3, 5; TGR 4, 5. Uma série considerada inteligente foi relacionada à criatividade para AGR 3; e TGR 4 e, ainda, o que é criativo está subentendido no visual da coreografia, para o árbitro AGR 4 e para os técnicos TGR 2, 6, 8, 9.

A expressão corporal da ginasta deve ter a participação de todos os segmentos corporais em movimento, atrelada à sua expressão facial, de forma a comunicar o tema da música e a mensagem da composiçãa ${ }^{17}$. Outros elementos que integram os componentes de dificuldade foram valorizados no Código 2013-2016: a maestria dos aparelhos e combinaçóes de passos de dança $\mathrm{a}^{17}$. Ambos trazem a compreensão e a percepção de beleza deste esporte. Torna-se relevante reforçar que esses aspectos anteriormente citados foram mantidos no Código atual, 2017-2020. Para os participantes desse estudo, dança e maestria são elementos por meio dos quais a criatividade, tanto dos técnicos quanto da ginasta se ressalta.

A maestria foi destacada por 06 participantes (AGR 2, 5; TGR 3, 5, 7, 9). No Código de Pontuação 2013-2016, esta é descrita como uma dificuldade de aparelho, um elemento de originalidade, o qual consiste em algo que seja extraordinário, único, que só será validada se estiver declarada na ficha da ginasta, se não houver falta técnica, erros e se for considerada pela arbitragem pela combinação de diferentes elementos ${ }^{30}$. Uma maestria é algo não ordinário, incomum, diferente e, portanto, tem que ser criativo para ser elaborado e para conquistar a pontuação (AGR 5). Sendo assim, aqui a criatividade se torna algo imperativo.

Importante salientar que, no Código de pontuação 2017-202039, os elementos chamados maestria foram substituídos por Dificuldades do Aparelho $(\mathrm{AD})$. Portanto, o que necessitava ser extraordinário, 
incomum e diferente, passa a ter também a exigência de ser difícil e englobar a sincronização de elementos do aparelho e do corpo, de maneira interessante e inovadora. Outra modificação a ser apontada, se refere às fichas de dificuldade das séries não estarem presentes no Código 2017-2020 39 .

Os passos de dança devem ter, no mínimo, 08 segundos e apresentar variedade de níveis, direções, velocidade, bem como serem elaborados com planos de movimento diversificados. A ginasta deve manter o aparelho sempre em movimento e um bom deslocamento pelo espaço delimitado. Os padrôes rítmicos devem estar de acordo com o estilo musical e modalidade escolhida (dança de salão, dança moderna, dança popular, ou outra $)^{30}$. As associaçóes da criatividade na combinação e composição dos passos de dança foram apontadas pelos participantes AGR 2, 3, 5; TGR 2, 3, 4, 5, 6, 7, 8, 9 como um fator essencial.

A criatividade não está incluída nos formulários de avaliação de uma forma direta e específica, contudo, para todos os árbitros e técnicos, a criatividade foi descrita como um item importante seja na avaliação, ou no treinamento e elaboração das rotinas e séries de GR, inclusive, para que a atleta não utilize sempre os mesmos elementos em suas coreografias (TGR 2, 3). Conforme salientado pela TGR 8, é um componente essencial e, para a TGR 6, "quase todos os elementos da ginástica rítmica dependem de movimentos criativos."

Assim, todos afirmaram que essa capacidade auxilia e favorece o desempenho da atleta, sendo, justamente, o que diferencia a ginasta (AGR 1, 2, $3,4,5$; TGR $1,2,4,5,7,9)$ e o que enriquece a composição da série (AGR 1, 2, 3, 4, 5; TGR 1, 2, 4, 5, 7, 8, 9). Os participantes considerados mais criativos são os que apresentam os melhores desempenhos, para os seguintes entrevistados: AGR 2, 3, 5; TGR 2, 3, 4, 5, 7, 8. Entretanto, quando a criatividade é utilizada de forma inadequada, pode vir a atrapalhar (AGR 1, 2, 4, 5; TGR 1, 4, 5, 6, $7,8,9)$, especialmente se os movimentos gímnicos estiverem permeados por erros, ou estiverem fora de contexto (AGR 1, 2, 4, 5; TGR 1, 3, 5, 6, 7, 9). É necessário ter cuidado ao inserir algo novo na coreografia: "às vezes o técnico coloca uma coisa boa que não vale de nada e ainda perde nota por ter feito errado" (AGR 2) .

As notas atribuídas à ginasta em uma competição de GR são o resultado das deduçôes de pontos feitas de acordo com a quantidade de erros que a atleta comete.
Além disso, os valores de cada dedução são específicos para cada tipo de falha cometida, dependentes da qualidade técnica e artística de cada movimento, do elemento corporal e do aparelho apresentado.

Nas competiçóes regidas pelo Código de Pontuação 2013-2016, uma nota de partida era previamente declarada na ficha da ginasta de acordo com seu nível técnico, categoria e com a competição em $\mathrm{si}^{34}$. Ao final de uma apresentaçáo de GR, cada árbitro atribuia uma nota de 0 a 10 pontos, considerando o quesito pelo qual é responsável. Posteriormente, as notas mais altas e as de menor valor eram descartadas e as notas centrais tomadas como base para se calcular a média ${ }^{30,34}$. No Código 2017-2020, a forma de obtenção da nota final foi revista. Atualmente, a pontuação final de um exercício deve ser estabelecida por meio da adição das notas atribuídas pelos árbitros de Dificuldade e de Execução ${ }^{39}$.

Para que a atleta se mantenha no auge de seu desempenho por mais tempo e para que atenda às demandas de organização e planejamento no desenvolvimento da modalidade, visando uma participação de excelência nos mais diversos eventos competitivos de GR, torna-se premente o aumento da criatividade dos treinadores e técnicos envolvidos, diversificando conhecimentos frente às tomadas de decisão necessárias e as variáveis envolvidas no treinamento da atleta ${ }^{34}$. Isso também foi relatado na entrevista com a AGR 1, para quem a criatividade está diretamente ligada à treinadora.

O presente estudo ressalta a necessidade dessa capacidade desenvolvida dentro de um processo que é também cognitivo, considerando os profissionais que pensam e criam a coreografia e, inclusive, nas próprias atletas, dada as relaçóes existentes entre os aspectos expressivos, artísticos e a compreensão dos fundamentos técnicos e regulamentos envolvidos em sua performance. Para a TGR 8, essa importância da criatividade perpassa a capacidade da ginasta em transcender as expectativas de melhores composições, surpreender e ultrapassar limites. Para TGR 2, é o que cativa, chama a atenção, traz mais prazer em assistir a série.

Ainda entre os entrevistados, foi destacado o fato de que a percepção do que é criativo atrai o árbitro AGR 5, TGR 5. Já para outros (AGR 2; TGR 7, 9), o que é criativo vai além do que se tem como padrão de melhor ginasta, ou como a melhor série. O criativo, para eles, modifica os referenciais existentes, ou seja, pode transformar a ginasta e sua série em uma referência na percepção e julgamento do que seria o melhor 
desempenho para futuras geraçóes.

A TGR 6 salienta que, todo esse desenvolvimento do potencial criativo, depende de como a criatividade é utilizada e de que forma está incluída na rotina de trabalho da atleta. No treinamento das ginastas, sobretudo em início de envolvimento com o esporte, a criatividade se torna essencial para que as crianças não acabem se desmotivando dos treinos (TGR 3) e, ainda, para que elas não se limitem a reproduzir o que o técnico passou, e "...consigam colocar, nos seus movimentos e gestos, a imagem delas.” (AGR 2).

Para tanto, é preciso que, no treinamento, o técnico crie situaçóes que visem desenvolver a autonomia dessas atletas, para que busquem novas possibilidades e explorem esses movimentos de forma mais livre (TGR 1, 7, 8, 9). Outra estratégia citada foi estimular sempre, por meio do uso de músicas diversas e, então, deixar que elas criem "coreografias individuais", ou seja, as próprias coreografias, a partir do que aprenderam (TGR 4, 7). Além disso, é preciso cuidar para "...não podar essa criatividade.” (TGR 4), o que implica em gerar situaçóes para se explorar a capacidade criativa. Essa se torna uma estratégia valiosa para que a atleta exercite sua capacidade de expressar o que aprendeu, a partir da própria percepção, criando formas de transcender as técnicas e comunicar, por meio dos seus movimentos, seus sentimentos e conhecimentos, podendo, ainda, indicar caminhos para enriquecer e diferenciar as composiçóes.

LOUREnçO e BARbosa-Rinaldi ${ }^{36}$ enfatizam a música como uma ferramenta de extremo valor. Toda a execução da ginasta deve estar em perfeita harmonia com a música. A coreografia deve estar estruturada para que seja percebido o desenrolar da ideia guia da série, composta por elementos técnicos e estéticos interligados à expressão da ginasta e ao manejo do aparelho. Complementando essa discussão Ávila-Carvalho, Silva e Lebre ${ }^{38}$, ainda ressaltam que ainda que a composição seja responsabilidade do treinador, no momento da competição, a interpretação desse todo, é de inteira responsabilidade da ginasta. Isto significa a projeção de uma imagem artística e emocional da atleta, ou seja, uma interpretação que é expressiva guiada pelo acompanhamento musical, pela imagem artística e pela expressividade desta executante ${ }^{38}$ em que a criatividade se torna um elemento intermediador e enriquecedor para tanto

Estes apontamentos também foram feitos por 03 técnicos. Para TGR 1, as séries devem estar ligadas diretamente à música, sendo que a criatividade é o que enriquece a "história que a atleta tenta passar aos árbitros e público" (TGR 2) e algo que "se encaixa na série e flui" (TGR 7). Esse entendimento também foi destacado por 02 árbitros: "Quando você avalia um passo de dança, quando você avalia o contexto da série, a história guia da série, você acaba avaliando a criatividade." (AGR 5). "Uma série criativa é uma série com contexto, uma série que você consegue identificar o começo, o meio e o fim. que ela conta uma história junto com o fundo musical, em conjunto com a música." (AGR 3).

Entretanto, foram relatadas as dificuldades em avaliar, justamente pelo fato de que, arbitrando, esse árbitro vê a ginasta uma única vez, no momento da competição e, como geralmente quem monta a série é o técnico, julgar o que é criativo, ou mesmo a essência dessa série de forma justa, se torna complexo. (AGR 2). Muitas vezes, esse julgamento acerca do criativo acaba se limitando ao julgamento da composição da série. Portanto, para esse árbitro, nesse momento, uma estratégia utilizada por ele é "buscar sentir o que ela está querendo passar", o que reforça a subjetividade envolvida nesse processo. Para Debien et al ${ }^{40}$, a função de avaliador de desempenho das atletas, a responsabilidade por julgar uma competição de GR, por ter que tomar decisóes corretas e justas em curto período de tempo, devido a essa percepçáo permeada pela subjetividade e todo o contexto em que o árbitro se encontra inserido, se torna uma situação geradora de stress, o que pode interferir, inclusive na compreensão desta avaliação e, portanto, gerar divergências nos resultados.

Por meio dessas entrevistas, pode-se reforçar a existência de grandes desafios ainda a serem elucidados nas regras e julgamento dessa modalidade. Corroborando RusseLL ${ }^{41}$, este estudo reconhece as conquistas e a evolução da GR como um esporte que vem, a cada dia, se sobressaindo pelas formas inovadoras, pela beleza e excelência com que acontece a execução das performances ginásticas. Entretanto, por serem muito dedutivas e matemáticas, as recompensas pela criatividade e pela inserção de componentes artísticos podem ser sacrificadas a favor da exatidão de giros, acrobacias, excesso de flexibilidade articular e outros ${ }^{41}$. Como resultado, muitas vezes para não cometerem erros, atletas tendem a reproduzir séries idênticas, apenas alternando aparelhos, o que, para RusselL ${ }^{41}$, faz com que se perca a essência e as prerrogativas artísticas e expressivas, próprias dessa modalidade.

A GR tende a ser avaliada subjetivamente, 
tanto na análise dos aspectos técnicos, quanto na difícil tarefa de avaliar o mérito artístico e criativo. Dessa forma, na tentativa de se diminuir essa subjetividade, cada vez mais, as regras têm se tornado complexas, o que dificulta o julgamento ${ }^{41}$. Além disso, como os árbitros não acompanham o processo de criação das performances e nem as atletas em seu desenvolvimento esportivo, avaliar a criatividade se torna uma complexa dificuldade, pois analisam aquele momento específico e curto da apresentação como um produto final.

A abordagem técnica e artística daqueles que julgam as ginastas (árbitros) difere, muitas vezes, de quem as treina (treinadores). Por esse motivo, para Russell ${ }^{41}$ regras e julgamentos deveriam ser simplificados e se tornarem mais centrados e alinhados aos ginastas e treinadores.

Toda essa complexidade foi amplamente ressaltada nas respostas dos participantes para esse estudo, para os quais a criatividade significa essencialmente expressar o novo, o diferente, com perfeição e se adequar ao contexto sem perder de vista a beleza e a essência da performance. Contudo, o que é percebido como criativo só será valorizado se houver o atendimento às exigências dos regulamentos técnicos com perfeição, em que a ginasta consiga expressar uma mensagem por formas diferenciadas, prevalecendo a apresentação das relaçóes harmoniosas entre seu domínio corporal, música, estilo escolhido e aparelho, o que implica em utilizar e desenvolver o que Moraru, Memmert e Kamp ${ }^{42}$, Domínguez, Pereira e Vidal ${ }^{43}$ destacam como criatividade motora: capacidade de gerar e apresentar soluçóes originais e diferentes, a partir da combinação de flexibilidade e fluência de ideias associadas por meio do domínio de novas tarefas motoras.

Devido à exigência de um desempenho livre de erros, o valor desse potencial criativo é percebido entre atletas e competiçóes de alto rendimento, ou seja, atletas de elite, com níveis técnicos mais elevados. Para todos, são elas que melhor atendem às expectativas e orientaçôes presentes, inclusive no Código de Pontuação, de que a composição da série elaborada para uma competiçáo apresente variedade no uso dos elementos corporais, bem como, um manejo de aparelho diversificado. Ainda, para uma maestria, (ou Dificuldade de Aparelho, de acordo com o termo atual desse tipo de movimento, conforme descrito no Código 2017-2020) ser validada pela banca de Dificuldade, deverá ser concebida e percebida como algo extraordinário, apresentar originalidade e perfeição.
Por esse motivo, entre os técnicos, o treinamento foi salientado como o ambiente propício para o desenvolvimento do processo criativo e, de igual modo que os movimentos, sejam explorados de forma criativa, juntamente com momentos para dar a elas a oportunidade de desafiarem suas habilidades técnicas e cognitivas, por meio de vivências prazerosas, podendo inclusive, o lúdico incentivar novas aprendizagens. Para tanto, essas estratégias devem ser inseridas desde a infância, para compor a formação de atletas cada vez mais criativos.

Além da Dificuldade, a criatividade é conjugada como um fator primordial na avaliação dos componentes artísticos, julgados por sua coesão com os elementos técnicos pela banca de Execução. Em ambas as avaliações, banca de Dificuldade e de Execução, os passos de dança são descritos como elementos corporais, em que a criatividade, expressa em forma de movimento corporal (criatividade motora), se configura por atrair a atençáo e emocionar a quem assiste à apresentação, ou seja, como um componente que interfere na decisáo da arbitragem e, portanto, na nota da ginasta.

Entre outros, destacam-se ainda as questóes relacionadas à complexidade envolvida no julgamento do mérito artístico, na execução e composição de uma série ginástica, o que implica em sensibilizar esse olhar para além do rendimento e perfeição técnica, de forma a se centrar um pouco mais na ginasta, na arte que ela expressa. Nesse sentido, também o potencial criativo, tanto dos técnicos, como da própria atleta, ganha relevância.

A importância da criatividade foi salientada, por favorecer, tanto aspectos expressivos e artísticos, como os técnicos, sendo igualmente reforçada a subjetividade e a sensibilidade como fatores norteadores, capazes de orientar ou influenciar as decisóes dos membros das bancas de arbitragem. Para este estudo, a criatividade é vista como uma capacidade avaliada como um todo coeso, conforme destacado entre os participantes. Tanto na avaliação das dificuldades, como da execução, é o que substancialmente contribui para a definição da melhor ginasta e da melhor série, até mesmo, pela forma subjetiva com que a série considerada mais criativa é percebida e atrai o olhar e afinidade dos árbitros e do público, o que torna ambas, atleta e série, uma referência para as próximas competiçôes e o que se configura como a essência desse esporte. Por esses motivos, reafirma-se a importância do estímulo e apropriação do potencial criativo desde o início do treinamento das atletas. 
No entanto, devido às habilidades motoras exigidas e por envolver um alto grau de competitividade, aspectos técnicos e o virtuosismo se tornam fatores de maior valor, fazendo com que o treinamento se limite às repetiçóes e reproduçóes de desempenhos tidos como padrão e referência nesse esporte, negligenciando aspectos expressivos, artísticos e criativos. Portanto, essas perspectivas ainda merecem ser reavaliadas nos regulamentos esportivos da modalidade.

Conforme salientado nas entrevistas, a GR é um esporte de natureza artística, o que incita reflexóes quanto às formas de avaliar que abarquem os universos tanto das artes como do esporte. No entanto, este estudo se limitou a investigar uma pequena amostragem de árbitros e técnicos, sendo, ainda, necessário o desenvolvimento de novos estudos, os quais focalizem a percepção de outros árbitros e, até mesmo, das próprias atletas a esse respeito.

Além disso, persiste a dificuldade em se criarem métodos e ferramentas precisas para a avaliação da criatividade, ainda que esta seja reconhecida como essencial para o esporte. Atualmente, podese apontar para a confluência entre áreas, como Educação, Psicologia, Artes, Educação Física, Ciências da Motricidade e Saúde, além de outros conhecimentos relacionados a esta prática, capazes de ampliar as perspectivas para o aprimoramento desse esporte.

Sendo assim, ainda existem inúmeros vieses a serem explorados e, portanto, a necessidade de novas discussóes e pesquisas acadêmicas no âmbito dessa temática. Outros estudos poderiam inclusive confrontar esses dados com base nos códigos mais atuais. Ainda, estudos que abordem a concepção das atletas, as dimensôes da criatividade em seu treinamento, bem como, nas metodologias e estratégias pedagógicas poderiam trazer informaçóes relevantes para se pensar as performances, a criatividade, as subjetividades e as regras esportivas, como fatores responsáveis e interligados na qualidade do produto final apresentado em uma competição de GR.

\section{Notas}

a. O presente estudo é parte da Tese de Doutorado apresentada ao Programa de Ciências da Motricidade, UNESP, Instituto de Biociências, Departamento de Educação Física, campus Rio Claro: Trevisan PRTC. Criatividade motora na Dança Esportiva e na Ginástica Rítmica: percepção subjetiva de técnicos e árbitros [tese]. Rio Claro (SP): Universidade Estadual Paulista; 2016.

b. No Código de Pontuação da GR, o termo originalidade diz respeito à criação de um elemento considerado inédito, o qual, ao ser aprovado, é incorporado ao Código de Pontuação e recebe o nome da ginasta que o executou pela vez. Além disso, será concedida pontuação extra a essa ginasta, por executá-lo no exercício.

\section{Agradecimento}

Agradecimento especial a CAPES pelo apoio financeiro para o desenvolvimento da pesquisa. 


\section{Abstract}

Subjective perception about creativity: gymnastics rhythmic referees and coaches point of view

This qualitative study investigated the judgment parameters in the subjective perception about creativity of referees and in Rhythmic Gymnastics technicians' point of view. Therefore, in addition to the bibliographic research, an exploratory survey was conducted considering the perception of this referees and technicians about the creativity and the involvement of this capacity in the development and in its judgment under the competitive scope. As data collection instrument, a semi-structured interview was conducted by questions specifically prepared for this study, which was individually applied to an intentional sample selected by convenience, composed by 14 participants of both sexes, $05 \mathrm{GR}$ referees with ages range between 23 and 46 years and experience of 04-22 years, and 09 GR technicians aged also between 23 and 46 years, 06-20 practice time years. All of them were active in national competitions in the duration of the Olympic cycle 2013-2016. Data were descriptively analyzed by Content Analysis Technique and indicated that these participants highlighted the creativity as the ability to express the new, the different, in an extraordinary way, perfect and appropriate to the demands of this sport. As its importance is subjectively perceived, these interviewees emphasized the creative potential relevance to enrich expressive, artistic and technical aspects in the athletes' performances. Although, the creativity judgment in a competitive context does not represent a criterion immediately set out in the codes, this is done in a subjective way, which is perceived as a cohesive whole expressed as an artistic content of the series, considering both, as elements of difficulty and as elements of execution. These results contribute to new reflections to increase the understanding of creativity, sport and refereeing relationship.

KEYWORDS: Gymnastics; Motor creativity; Sport; Refereeing.

\section{Referências}

1. Harris A. Creativity and education. London: Springer, 2016.

2. Baer J. Creativity doesn't develop in a vacuum. In: Barbot B, editor. Perspectives on creativity development: new directions for child and adolescent development. San Francisco: Spring, 2016. p. 9-20.

3. Simóes J, Fernando C, Lopes H. Creativity in Physical Education. J Curr Res Sci. 2016;4:125-9.

4. Kaufman JC. Creativity 101.New York: Springer Publishing Company, 2016.

5. Wechsler SM, Nunes MFO, Schelini PW, Ferreira AA, Pereira DAP. Criatividade e inteligência: analisando semelhanças e discrepâncias no desenvolvimento. Estud Psicol. 2010;15:243-50.

6. Samulski DM, Noce F, CostaVT. Principais correntes de estudo da criatividade e suas relaçóes com o esporte. Movimento. 2001;7:57-66.

7. Memmert D, Baker J, Bertsch C. Play and practice in the development of sport-specific creativity in team ball sports. High Ability Stud. 2010;21:3-18.

8. Temme D, Temme T, Ercenk-Heimann D. The problem of strategies of volitional control of movement for movement quality and movement creativity.6. International TGFU Conference and 10 dvs Sportspiel Symposium Meets; 2016; Cologne, GER. Abstracts. Res Quart Exerc Sport. 2016;87(Suppl 1):95-6.

9. Memmert D. Fostering young talents: the case of tactical creativity. 6. International TGFU Conference and $10 \mathrm{dvs}$ Sportspiel Symposium Meets; 2016; Cologne, GER. Abstracts. Res Quart Exerc Sport. 2016;87(Suppl1):56.

10. Brikman L. A linguagem do movimento corporal. 3a. ed. rev. São Paulo: Summus, 2014.

11. Sternberg RJ, Lubart TI. The concept of creativity: prospects and paradigms. In: Sternberg RJ, editor. Handbook of creativity. New York: Cambridge University Press, 1999. p. 3-16.

12. Lubart, TI. Psicologia da criatividade. Porto Alegre: Artmed, 2007.

13. Trevisan PRTC. A expressão da criatividade na dança [dissertação]. Rio Claro (SP): Universidade Estadual Paulista, Instituto de Biociências, Departamento de Educação Física, 2010. 
14. Mohamed SHF. Effect of motor improvisation on motor creativity and vanillylmandelic acid (VMA) in rhythmic exercises in girls at Faculty of Physical Education. JASS. 2015;5:118-125.

15. Vidal A. La dimensión artística de la Gimnasia Ritmica Deportiva: análisis del conjunto como acontecimento coreográfico. Cuaderno Técnico-Pedagógico. La Coruña: Centro Galego de documentacion e edicións deportivas, 1997.

16. Coellho JE. Inserção dos meninos no universo cultural da Ginástica Rítmica: pesquisa-ação na Federaçáo Riograndense de Ginástica [tese]. Porto Alegre (RS): Universidade Federal do Rio Grande do Sul, Escola de Educaçáo Física, 2016.

17. Toledo E, Antualpa K. The appreciation of artistic aspects of the Code of Points in Rhythmic Gymnastics: an analysis of the last three decades. Rev Bras Educ Fís Esporte. 2016;30:119-131.

18. Amengual M, Lleixà T. La creatividad motriz em gimnasia rítmica deportiva em edad escolar. Rev Intern Med Cienc Actividad Fís Deporte. 2011;11:548-63. Disponível em: http://cdeporte.rediris.es/revista/revista43/artcreatividad233. pdf.

19. Cavalcanti LMB, Porpino KO. O sofrimento e a dor como constituintes da beleza esportiva: reflexóes para a educação. Holos. 2015;5:401-413.

20. Ávila-Carvalho MLT. Ginástica Rítmica de alto rendimento desportivo: estudo de variáveis do desempenho na especialidade de conjuntos [tese]. Porto (POR): Universidade do Porto, Faculdade de Desporto, 2012.

21. Robin JF, Santos SB. Ginástica: um jogo de regras. In: Schiavon LM, Bortoleto MAC, Numemura M, Toledo E, organizadores. Ginástica de alto rendimento. Várzea Paulista: Fontoura, 2014. p. 151-170.

22. Bardin L.Análise de conteúdo. 6a. ed. Lisboa (PO): Ediçôes 70, 2011.

23. Silva AH, Fossá MIT. Análise de Conteúdo: exemplo de aplicação da técnica para análise de dados qualitativos. Qualitas Rev Eletr. 2015;17:1-14.

24. Huber GL, Gürtler L. AQUAD 7 manual: the analysis of qualitative data. Tübingen: Softwarevertrieb Günter Huber, 2013.

25. Oliveira KS, Wechesler SM. Indicadores de criatividade no desenho da figura humana. Psicol Ciênc Profissão. 2016;36:619. Disponível em: http://www.scielo.br/pdf/pcp/v36n1/1982-3703-pcp-36-1-0006.pdf.

26. Tibeau CCPM. Concepçóes sobre criatividade em atividades motoras. Rev Bras Ciênc Mov. 2002;10:33-42. Disponível em: https://portalrevistas.ucb.br/index.php/RBCM/article/viewFile/447/473.

27. Boaventura PLB. Possibilidades de transformaçáo da Ginástica Rítmica em esporte-conteúdo nas aulas de Educação Física escolar. Cad Formação RBCE. 2014;5:45-55. Disponível em: http://revista.cbce.org.br/index.php/cadernos/ article/view/2050/993.

28. Pereira HCMC. Ginástica Rítmica: um conserto para o corpo [dissertação]. Natal (RN): Universidade Federal do Rio Grande do Norte, Centro de Ciências da Saúde; 2014.

29. Cavalcanti LMB. Beleza e poder na Ginástica Rítmica: reflexôes para a Educação Física [dissertação]. Natal (RN): Universidade Federal do Rio Grande do Norte, Centro de Ciências Sociais Aplicadas, 2008.

30. Fédération Internationale de Gymnastique. 2013 - 2016 Code of Points - Rhythmic Gymnastics - FIG; 2015. Disponível em: http://www.fig-gymnastics.com/publicdir/rules/files/rg/RG\%20CoP\%202013-2016\%20valid\%20 1st\%20January\%202015_e.pdf.

31. Frutuoso AS, Diefenthaeler F, Vaz MA, Freitas CR. Lower limb asymmetries in rhythmic gymnastics athletes. Int J Sports Phys Ther. 2016; 11:34-43. Disponível em: http:/www.ncbi.nlm.nih.gov/pmc/articles/PMC4739046/.

32. Silva LMF, Porpino KO. Esporte como experiência estética e educativa: uma abordagem fenomenológica. Holos. 2014;5:64-80. Disponível em: http://www2.ifrn.edu.br/ojs/index.php/HOLOS/article/view/2557/pdf_96.

33. Huggins M. O olhar esportivo: para uma virada visual na história do esporte - documentando arte e esporte. Recorde: Rev Hist Esporte. 2014;7:1-40. Disponível em: https://revistas.ufrj.br/index.php/Recorde/article/view/1322/1223.

34. Debien PB. Monitoramento da carga de treinamento na Ginástica Rítmica: efeitos no estado de recuperação, perfil hormonal, resposta imune e desempenho físico [dissertação]. Juiz de Fora (MG): Universidade Federal de Juiz de Fora, Faculdade de Educação Física e Desportos, 2016.

35. Bortoleto MAC. O caráter objetivo e o subjetivo da Ginástica Artística [dissertação]. Campinas (SP): Universidade Estadual de Campinas, Faculdade de Educação Física, 2000.

36. Lourenço MRA, Barbosa-Rinaldi IP. O conjunto na Ginástica Rítmica. In: Schiavon LM, Bortoleto MAC, Nunomura M, Toledo E, organizadores. Ginástica de alto rendimento. Várzea Paulista: Fontoura, 2014. p.43-64.

37. Santos JB, Toledo E, Reis PF, Moro ARP, Gomes AC. Perfil postural de atletas de ginástica rítmica na faixa etária de 10 a 19 anos no estado de São Paulo. Rev Bras Prescrição Fisiol Exerc. 2016;10.395-404. Disponível em: http://www. rbpfex.com.br/index.php/rbpfex/article/view/987. 
38. Ávila-Carvalho MLT, Silva CPLS, Lebre E. O conteúdo dos exercícios de competição em Ginástica Rítmica. In: Schiavon LM, Bortoleto MAC, Nunomura M, Toledo E, organizadores. Ginástica de alto rendimento. Várzea Paulista: Fontoura, 2014. p. 107-130.

39. Fédération Internationale de Gymnastique. 2017 - 2020 Code of Points - Rhythmic Gymnastics - FIG; 2017. Disponível em: http://www.fig-gymnastics.com/publicdir/rules/files/rg/RG_CoP\%202017-2020_updated\%20 with\%20Errata_February\%202017_e.pdf.

40. Debien PB, Noce F, Debien JBP, Costa VT. O stress na arbitragem de Ginástica Rítmica: uma revisão sistemática. Rev Educ Fís/UEM. 2014;25:489-500. Disponível em: http://www.scielo.br/pdf/refuem/v25n3/1983-3083refuem-25-03-00489.pdf

41. Russell K. Desafios da ginástica: uma visão de 50 anos de experiência como técnico e em ensino. In: Schiavon LM, Bortoleto MAC, Nunomura M, Toledo E, organizadores. Ginástica de alto rendimento.Várzea Paulista: Fontoura, 2014. p. 25-41.

42. Moraru A, Memmert D, Kamp J. Motor creativity: the roles of attention breadth and working memory in a divergent doing task. J Cognitive Psychol. 2016;28:1-12. Disponível em: https://www.dshs-koeln.de/fileadmin/redaktion/institute/ kognitions_und_sportspielforschung/publikationen/paper/moraru_2016_motor-creativity.pdf.

43. Domínguez A, Pereira MPD, Vidal AM. The evolution of motor creativity during primary education. J Human Sport Exerc. 2015;10:583-91. Disponível em: http://dx.doi.org/10.14198/jhse.2015.102.05.

\begin{tabular}{r|l} 
ENDEREÇO & \\
Priscila Raquel Tedesco da Costa Trevisan & Submetido: 10/08/2017 \\
Avenida 24 A, s/n & Revisado: 23/06/2018 \\
13506-900 - Rio Claro - SP - Brasil & Aceito: 20/05/2021 \\
E-mail: priscilalel28@gmail.com &
\end{tabular}

Rev Bras Educ Fís Esporte, (São Paulo) 2021 Abr-J un;35(2):321-341 • 341 